\title{
News Media and Immigration in the EU: Where and How the Local Dimension Matters
}

\author{
Andrea Pogliano
}

Due to their quasi-monopoly in the articulation of symbolic power (Thompson 1995), the media play a key role in the production of public discourses on most public issues, including those associated with immigration and ethnic minorities. They provide frameworks of explanation. They also furnish codes that label and classify. The media are therefore privileged sites for the production of differences in the public discourse and for the provision of moral judgements related to several publicly relevant issues. Although these claims have few, if any, opponents they are unfortunately only rarely corroborated by research on the effects of media representations on immigration and ethnic minority issues. The relatively few studies available on this topic are unevenly distributed across countries. They are quite numerous in countries such as Germany and the Netherlands and, to a lesser extent, in France, Denmark and Sweden, but they are completely missing in many of the EU states (ter Wal 2002; Bennett et al. 2011). Due to the impossibility of comparing studies on media effects, the section of this chapter devoted to showing commonalities and differences in the EU regarding the contribution of the news media to discourses on immigration and ethnic minority issues will concentrate on the texts, i.e., on the journalistic representations, and partly - and mainly indirectly - on typical newsmaking mechanisms.

The general aim of this chapter is to analyze selected empirical data from that collected for the media section of the Concordia Discors project ${ }^{1}$ within a

\footnotetext{
${ }^{1}$ For the Concordia Discors project a keyword search was conducted on two daily newspapers for every neighbourhood considered, samplling issues every fifth day for the period 2001-2010 (with variations for practical reasons in the cases of London and Budapest). For this particular strand of Concordia Discors research, 14 newspapers overall were examined: 5 in Italy, 3 in Germany, 2 in the UK, 2 in Spain and 2 in Hungary. The newspapers include the following: in Italy, the local pages of the national dailies La Stampa and La Repubblica for the two neighbourhoods in Turin,
}

A. Pogliano $(\square)$

Università del Piemonte Orientale, Alessandria, Italy

e-mail: andrea.pogliano@sp.unipmn.it 
comparative European framework in order to examine the role played by the local dimension in media representations of immigrants and ethnic minorities. Local media have often been the target of studies examining the representations of immigrants and ethnic minorities. Nevertheless, these studies lack a comparative framework at both the national and international levels. Furthermore, only very few analyses of local media have focused on the hyper-local level of the neighbourhood. In those few cases, the aim was very often to analyze a single event covered by the local media over a brief period of time. This is partly explained by the fact that a number of studies focusing on local media dealt with local policies. In this regard, it is well known that news production is structured in relation to the political-administrative organization of local communities and their institutionalized relations with different levels of state bureaucracy (Ekström et al. 2012). This usually means an over-representation of the municipality and of larger scale administrative organizations (i.e. the Province and the Region) and an under-representation of the hyperlocal level, which is generally seen as having little, if any, power in implementing policies.

The media analysis element of the Concordia Discors project is a first attempt towards a comparison of neighbourhoods in local media representations of migration issues. Such an approach is aimed at questioning the impact of a series of variables implied in the media-making of symbolic boundaries. The process involves localities at different scales, groups of residents, non-residents, local organizations and city administrators. Our approach raises questions such as the power of neighbourhoods in determining or countering media narratives and labelling. As a result of the comparative analysis of neighbourhoods in local media representations, we argue against the typical claim that a more balanced (less negative) representation of immigrants and ethnic minorities can necessarily be achieved through the involvement of these actors in the production of news, referring to them both as news sources and as actors to be quoted. We see this point as absolutely urgent and important, but we do not see it as the only solution to the problem. We argue that matters are more complex and problematic. What we see from our data is a picture in which neighbourhoods that share a vital narrative (renewed through rituals and events) are more able than others to control and frame the news referring to them including that which refers to immigrants and ethnic minorities in the neighbourhood. This capacity to keep control of the narrative does not necessarily mean enhanced visibility for immigrants and minority groups. It could even mean just the opposite, depending on the context.

the local pages of La Repubblica for the two neighbourhoods in Genoa; and the local pages of $L a$ Repubblica and Corriere della Sera for the neighbourhood in Milan. In Germany, the local dailies Nürnberger Zeitung and Nürnberger Nachrichten. In Spain, local pages of the national daily La Vanguardia and city pages of the regional daily El Periódico de Catalunya. In the UK, the local bi-weekly South London Press and city pages of the regional weekday daily Evening Standard. In Hungary, the hyper-local bi-weekly Józsefváros and the hyper-local monthly Kóbányai Hírek. We do not deal with all these data but only with that relevant to the main topics to be discussed in this chapter. 
The structure of this chapter is as follows: the first section is on common trends and major differences on this topic across EU countries. Although a serious comparison is far from being accomplished, and is, perhaps, even impossible due to significant differences in their histories, policies, media environments and social contexts, we nevertheless describe key commonalities and differences that seem to emerge from important studies in the field.

The second section is devoted to investigating the scale of these representations, questioning the geographic level of the framing of the news on immigration. We consider national, local and hyper-local levels in their reciprocity, looking at their clear divergences, overlaps, and mutual reinforcements. We then present a framework for reasoning on this topic.

We investigate different modalities used to produce news stories related to neighbourhoods and migration, labelling or not labelling the neighbourhoods in relation to the presence of immigrants or ethnic minorities settlements, by providing empirical data from the media section of the Concordia Discors project. We stress the opposing notions of narrative cohesion and narrative fragmentation by comparing the data about local media representations from Concordia Discors case studies. Narrative cohesion and narrative fragmentation at a hyper-local level are part of a wider process determining and being determined by the images of neighbourhoods resulting from the news. These images may be the product of a labelling process involving immigrants and ethnic minorities.

Thereafter, we discuss - with data from local media representations of four neighbourhoods - successful and failed episodes of 'moral panic' as ambiguous and controversial processes in which, we argue, narrative cohesion and narrative fragmentation within a given neighbourhood are key variables.

The main concepts used in the analysis are those of 'labelling' and 'moral panics'. The importance of labelling in media representations of persons, groups and places has been repeatedly evoked in media studies, especially following the 'cultural turn', and it is undoubtedly a very fruitful concept for studying the production of differences (related to class, gender and ethnicity) in the media. Both in studies adopting a quantitative content analytical approach and in those adopting a qualitative discourse analytical approach, the question of how the media uses labels to construct social categories and trace symbolic boundaries is critical. In the study of media representations of immigrants and ethnic minorities, we might assert that the concept of labelling together with that of stereotyping are the most commonly used in the analyses of the discursive boundaries separating natives and immigrants and/ or different racial or ethnic groups. Conceptualizing labelling as a social production involving the media and other actors who have some power in publicly challenging or restoring the social order generally means giving careful consideration to the power of discourses and symbols in shaping reality. The symbolic order is both a product of the interactions among media, authorities, administrations, organizations and public opinion, and a powerful reality in itself, triggering feedback loops from all of the aforementioned actors. The process of labelling is an important component of several media-driven phenomena when analyzed within a social constructionist approach. Among these phenomena, moral panic takes centre stage. In its 
first formulation by Cohen (1972), the supporting theory was indeed the symbolic interactionist theory of 'labelling' (cf. Becker 1963; Wilkins 1964), delineating deviant behaviour as interactive, i.e., the outcome of complex chains of social interactions in which the media plays a pivotal role. In further reformulations under different theoretical frameworks (i.e. ideology and hegemony; structural functionalism), the boundary-making approach produced within a labelling process remains key.

In moral panics, moral entrepreneurs play a key role, in some cases by being primary definers (Hall et al. 1978), offering journalists a frame within which to represent events. Among the moral entrepreneurs are politicians and government, police and law enforcement agencies, pressure groups and claims makers. These groups own the power to temporarily drive media narratives, especially when they form alliances. The ultimate function of successful moral panics is to shore up the existing moral order, reacting to social change. This is why studies of moral panic phenomena have focused on a wide and heterogeneous series of issues that are portrayed, at specific times and places, as threats to the moral order within a given society. They include the introduction of new technologies, the emergence of threatening viruses, such as AIDS in the 1980s, child abuse and other forms of physical abuse and new forms of deviance or criminality (for an overview of themes see Goode and Ben-Yehuda 1994; Thompson 1998; Critcher 2003). Immigrants and asylum seekers are often reported as being labelled as folk devils in some moral panic episodes, as will be described in Sect. 1.

In our analysis, moral panics on immigration are identified as an especially effective way of shaping the symbolic boundaries of interethnic societies. By labelling some groups as folk devils and by labelling some events with phrases such as 'interethnic clashes', moral panics gain a discursive legacy which is capable of triggering a series of national and local actors in a recursive game of representations, prescriptions and (political) actions. Furthermore, we argue that moral panics are very interesting phenomena to be studied in order to explore the geographic level of news framing on immigration and ethnic minority issues and the role played by neighbourhoods in determining the success or failure of a panic.

\section{News Media and Migration in EU States}

Although a large number of studies on journalistic representations of immigrants and ethnic minorities have been carried out in many EU states, very few works have attempted to conduct a comparative review of these studies. For our specific purposes, in this section we rely mainly (but not exclusively) on two reports in order to identify the main similarities and differences on the topic across Europe. The first report was edited by ter Wal in 2002 under the title Racism and cultural diversity in the mass media. Its conclusions offer a synthesis of common trends and differences reported in studies from 1995 to 2000 in 15 states. The second is the Mediva thematic report (Media Content), published in 2011, authored by Bennett et al. and 
which is partly intended as a temporal continuation of the previously mentioned report.

This section mainly focuses on Northern and Southern Europe. It lacks discussion of the potential specificity of East-Central Europe because only a very limited number of studies have been published on the topic of media and migration in this area. This also makes it difficult to conduct a rigorous comparative study of all of Europe.

\subsection{The Criminalization of Migrants and Media Self-Criticism}

A very generalized trend in the media representations of migrants and ethnic minorities across the EU is the over-emphasis on ethnic and immigrant crime. This means an over-representation of ethnic minority offenders in the news and, at the same time, a tendency - reported in studies carried out in different countries - to overlook the problems experienced by ethnic groups, including episodes of racist violence in which immigrants are the victims.

Analyzing five approaches in media research - the content analytical, the discourse analytical, the news-making, the social constructionist and the 'news and public attitudes' - Maneri and ter Wal tried to answer the "question of how and why, as research consistently shows, news on migrants is so often negative and so often about crime" (Maneri and ter Wal 2005: 2). Each of the five approaches offers a contribution to the discussion, by examining the extent to which migrants are overrepresented in the coverage of 'problem areas', by quantifying the topics on which the news stories tend to focus or not focus when dealing with immigrants and ethnic minorities, by discussing the importance of news-values and production routines, by qualitatively analyzing the ideological biases embedded in language, the role of political actors in producing biased reporting, the agenda-setting role of media effects on public opinion, and so on.

The news-making approach linked to the content analytical approach is particularly useful when thinking about news sources and the use of quotations. Indeed, another notorious general finding across the EU is that immigrants and 'ethnic, cultural, religious minorities [and NGOs supporting their voices] are not quoted very frequently and are not treated as regular news sources' (ter Wal 2002: 40). As an effect of a news-making mechanism, news and feature articles on immigrants rely heavily on politicians, official figures and the police as sources of information and explanation. 'With regard to news on deviance and crime, this means that official definitions of the situation (by the police and other officials) are likely to be prioritized and to receive prominent coverage as well as high credibility' (van Dijk 1988, in Maneri and ter Wal 2005: 6).

Important factors of differences between countries on this key topic of media representations are self-criticism and third actor (NGOs and/or local authorities) driven media practices. Self-criticism refers to 'initiatives of media organizations and individual journalists to elaborate (or demand the elaboration of) non- 
discriminatory texts' (Banon-Hernàndez 2002: 191). Journalists' associations and unions have tried to change reporters' attitudes about ethnic, cultural and religious differences, by promoting the use of guidelines and training facilities. This has happened sometimes nationally, sometimes locally, and with significant differences both in terms of the period in which they were introduced and of their effectiveness - between localities and nations. In some cases some code of conduct on the topic is shared within a 'journalistic community' even in the absence of written guidelines. This sharing may be recognized as a journalistic tradition in some countries (i.e. the tradition of not mentioning nationality or ethnic origins in crime news in the Netherlands). Quoting the Mediva thematic report, 'German and Dutch media do not mention nationality generally, in Germany this appeared to be a recent practice attributed to greater awareness among journalists. Although in the Dutch media this tradition is long, interviews with journalists conducted for this project show that the practice is changing and some newspapers appeared less reluctant to mention nationality in reports' (Bennett et al. 2011: 12). In Spain a deontological code approved by the professional association of Catalan journalists referring to these practices has existed since $1992 .{ }^{2}$ Since then, the association has published a Stylebook on the Treatment of Ethnic Minorities and a guide entitled The Treatment of Multiculturalism in Journalism. In Italy, the negative practice of mentioning ethnic origins in crime news notoriously still prevails, but in 2008 a new nondiscriminatory text was promoted by a group of stakeholders including the Council of Journalists. ${ }^{3}$ The text furnishes guidelines for the adoption of proper terminology and also indirectly condemns the widespread practice of mentioning ethno-national origins in the news when not strictly necessary for informational purposes. In London and in other metropolitan areas in Northern Europe local newspapers often have an unwritten code of conduct discouraging the mention of individuals' ethnicities.

In general terms, some studies - particularly from the UK and Germany - support the thesis of a general increased awareness of these concerns among journalists and editors, which has resulted in more positive reporting practices. More cautiously, the 2010 EU Handbook of Integration (Niessen and Huddleston 2010) restated that the existence of journalistic codes and self-regulation does not in itself prevent unfair and discriminatory discourse about immigrants and immigrant groups.

In an often quoted study on the British news media (Law 1997), the findings prompted the author to argue that news on ethnic minorities had "become the scene of an "anti-racist show", where increasing amounts of space were being given to the opinion of accredited minority actors' (Maneri and ter Wal 2005: 4).

Although these findings show inevitable ambivalences, they nevertheless trace a line between countries with recent histories of immigration and those with longer histories, reflecting improvement in media narratives on immigration and ethnic minority issues which appear to be, to some extent, directly proportional to the

\footnotetext{
${ }^{2} \mathrm{http}: / /$ www.periodistes.org/cic/html/body_codi_s.htm

${ }^{3} \mathrm{http}: / /$ www.odg.it/content/carta-di-roma
} 
length of time that migrant groups have been present in a given country. Although some local practices tell a different story (i.e. the deontological code of Catalan journalists), one might see these practices as the few exceptions confirming the rule.

\subsection{Newcomers and the Asylum Issue}

In the Mediva thematic report it is argued that in the UK "the media, especially tabloid, fail to distinguish sufficiently between economic migrants, asylum seekers and refugees" (Bennett et al. 2011: 12). Asylum seekers are often labelled as illegal immigrants. A similar finding emerges from the analysis of German TV discourse (Thiele 2005). We might argue that the label 'illegal immigrants' implies different levels of generalization in different countries. In countries of recent immigration, and in Italy in particular, it is used within a context of media reporting on immigration, which conspicuously over-represents landings, and the presence of illegal immigrants (clandestini). This label produces - especially but not exclusively in the conservative press - an arbitrary distinction between legal immigrants (perceived as good workers) and illegal immigrants (perceived as criminals or deviants), where the latter gain greater visibility than the former. Furthermore, in relatively recent immigration countries, the 'illegal immigrant' label does not imply the construction of, or necessarily overlap with a symbolic boundary between newcomers and older residents. ${ }^{4}$ On the contrary, in countries with a longer immigration history, it seems that the label of illegal immigrants runs precisely along the established resident/ newcomer boundary. Studies 'register a different treatment of the refugee and immigrant issue, on the one hand, and the issue concerning longer established ethnic minority communities, on the other' (ter Wal 2002: 42-43). For instance, scholars noticed that the general anti-racist tone of the British press (particularly the broadsheet press) on ethnic minorities is not extended to recent migration.

As has been emphasized in several studies, the news media typically adopt a double standard in framing stories of people fleeing persecution or escaping wars and disasters. In the foreign news they are always described as victims within a humanitarian framework, while in the domestic news they are very often described as intruders within a law and order framework (see, among others, Article 19: 2003).

This type of double standard is also typical within domestic news. In his analysis of the Belgian press coverage of the asylum issue, Van Gorp found that the representations of asylum seekers were almost equally distributed between 'a frame that referred to the archetypical role of the innocent victim... [and] a frame that referred to the stereotype "all strangers are intruders" (Van Gorp 2005: 489). The first frame was found to be more frequently used in the quality broadsheet press while the second was more frequently used in the popular press. The two frames have been

\footnotetext{
${ }^{4}$ This is not to say that media coverage has never led to stigmatization of various national groups during periods of high immigration of those groups (for example, of Albanian migrants to Italy in the 1990s and of Romanians in the following decade).
} 
described as radically distinct and each one develops a specific chain of connected reasoning devices (i.e. problem definition, problem source, responsibility, moral judgement, policy solution), news sources used and quotes referred to by journalists.

\subsection{Muslim Migrants and 'the Muslim Community'}

The Mediva thematic report found that in the 2000s one major theme in press reporting 'was that of Islam, linked with terrorism, cultural (in)compatibility, and Islamophobia (...) with a focus on aggression and threat' (Bennett et al. 2011: 12-13). The increase of studies on media and Islam after $9 / 11$ and $7 / 7$ is unsurprising, especially in the UK (among the most recent studies: Alsultany 2012; Flood et al. 2012; Hutchings et al. 2011; Karim 2011; Morey and Yaqin 2011). Islam has become such a central theme in the representations of immigration that, to some extent and mostly in Northern Europe, one could say - as Roggeband and Vliegenthart (2007) have with regard to the Netherlands - that immigration is now represented through the frame of Islam. This carries a shift from an emphasis on the ethno-nationalist dimension to the religious dimension. This shift has been described in the media representations of the Turkish minority in Germany, Austria and Switzerland (Krzyzanowski 2012; Yildiz 2009). This is particularly relevant in countries such as Germany, where 'Turks have tended to be covered as if they were representative of the entire range of 'foreigners' in the country' (Maneri and ter Wal 2005). A general increase in news reports about Muslims is documented in studies from many countries, but this seems to be more marked in Northern Europe.

This does not mean that before 9/11 Muslim migrants and Islam in the EU were not relevant themes in media representations. For instance, '[a]nti-Islamic tendencies in the Dutch press were particularly strong in the first half of the 1990s: for example, distinctions between religion and nationality were blurred, [and] Muslims were represented as a depersonalised collectivity' (ter Wal 2002: 48). We may find the same evidence in the studies conducted in Italy, where, apart from an increase in the number of news items on Muslim migrants (due to the connection with terrorism), the same stereotypes and tendencies to report on Muslims as part of a homogeneous community are found across the decades (Binotto and Martino 2004; Marletti 1995; Pogliano 2010; Pogliano and Zanini 2010; Soravia 2000).

\section{Re-articulating the Local/National Nexus in the News}

Analyzing the local in news media studies usually means analyzing local media. For immigration and ethnic minority issues the point is often to see if local media ascribe to these persons and groups the same negative portrayal that is typically found in the representations of national media. Local media vary from locally based 
TV and press to the local coverage offered by the national media. The local usually refers to a city or a broader area (the province or the region), but there are examples of more narrow-scale media, as in the case of the Budapest municipal free neighbourhood-level newspapers analyzed for the Concordia Discors project. In some cases, local media have been shown to be highly influential in defining local politics in relation to citizenship (Franklin and Murphy 1991, who however consider a peculiar context where a local newspaper enjoys a monopolistic position, which is less and less the case in the current media environment).

There is a sort of consensus in media studies in claiming that local media usually offer a more positive representation of immigrants and ethnic minorities than the national media. This claim has recently been made in the Mediva thematic report (see Bennett et al. 2011: 20). In particular, it is argued that migrants are more likely to receive positive coverage by local newspapers in metropolitan areas where the presence of migrants and ethnic minorities is stable and balanced (i.e. 'non majoritarian'). Notwithstanding this general consensus, studies show that while this finding applies to some northern European countries, it merits more critical discussion, particularly in reference to southern European countries. In Italy, the local media were found in some studies (Belluati 1998; Maneri 1998; Stopfner 2010; Stopfner and Vorhover 2011) to focus heavily on crime news and the mobilization of intolerance, using predominantly conflict and problem frames. According to these studies, the local media do not seem to be more sensitive than the national media in representing ethnic and cultural diversity. In contrast, other studies show a very different picture, revealing local media in some areas (i.e. the Emilia-Romagna and the Tuscany regions) to be more sensitive and to offer a more positive picture of immigration (Grossi 1995). It is often claimed that the local and regional media in Spain have been more sensitive towards solidarity and diversity than the national media, which nonetheless has also started to introduce more programmes reflecting cultural diversity. However, in both the Italian and Spanish regional cases, we notice that the studies producing these findings often refer to the tendency of local media to cover community events, festivals and other hyper-local events usually promoted by associations, NGOs and/or local authorities. The claim that the local media gives a voice to immigrants by quoting them more frequently than the national media do is very often based on news coverage of events that are unlikely to be the focus of national coverage. The local media has in some cases been more sensitive than the national media in promoting good practices. The cases of the Catalan Region in Spain and those of the Emilia-Romagna and Tuscany Regions in Italy are examples of practices of auto-regulation and media openness to new sources of information (i.e. grassroots associations, local NGOs) that anticipated and in some ways fostered innovations in the national media's sensibilities towards cultural diversity. Nevertheless, analysis of local and national media coverage of conflict events dealing with immigration has uncovered few significant differences. This is a topic that seems to be overlooked.

In the following pages, we will try to further examine the distinction between the national and the local in the media. We use events and images as key concepts. We are particularly interested in the process of de-localization and re-localization in 
describing and interpreting local events and in the images of localities (neighbourhoods in particular) that emerge from the media representations. ${ }^{5}$

To do so, we first need a framework for thinking about this reciprocity. We will therefore turn to the empirical data collected from the local media representations of four neighbourhoods, two from Turin and two from Barcelona.

\subsection{National, Local, Hyper-Local and the News Events: A Framework}

Not all news is local but all the events covered in the news are somehow local, in the self-evident sense that they happen in specific places. However, there are differences in their journalistic presentation. The difference we are interested in here is the geographical level of framing. Certain local events are presented from their first appearance in the news within a national frame, others are conceived to be local in the first instance. Still others are presented as hyper-local. We argue that in the construction of the national, local (usually the city level) and hyper-local (generally the neighbourhood level) what matters is the interrelation of three variables.

The first variable concerns the level of the discussion implied by a local event. Building a mosque is a local event inscribed in a national debate on multiculturalism, so it is an event that is more likely to be narrated within a national frame than, for instance, an episode of petty crime. Nevertheless, such distinctions are not easily drawn. Under particular circumstances a petty crime episode may be interpreted within a national frame. Two intervening variables are, in this case, news sources and the role played by moral/political entrepreneurs, as we will see below when discussing so-called 'moral panics'.

The second variable consists in the greater or lesser capacity of specific places to claim representativeness of a whole country. For instance, an event taking place in a big city that is also the headquarters of major media companies is more likely to be presented within a national frame than a similar event taking place in a small and peripheral city. Here again, the distinctions are not clear-cut. Some peripheral places have become central in the representation of an issue. For instance, the island of Lampedusa in Italy has become an intensely covered symbolical locus for the landing of undocumented immigrants and asylum seekers from North Africa. Lampedusa is a typical - and perhaps even extreme - case that sheds light on a common trend in media representations: very often the national centrality of local

\footnotetext{
${ }^{5}$ By de-localization we mean the process leading to the production of local news stories in which the local context is totally or partially omitted in favour of a national framework. By re-localization we mean the capacity of the local context to strike back, as a consequence of a visibility acquired by local actors or stakeholders gaining voice in local journalism. These processes may even be studied by taking the city and the neighbourhoods as elements to focus on, instead of a national and a - vaguely interpreted - local dimension.
} 
events, far from reinforcing the visibility of local concerns, instead produces an impressive lack of these concerns in the news.

A local variant of this second variable concerns the relationship between neighbourhoods and cities. As will be seen below, some neighbourhoods are described in the local news not only as part of the city but as its ideal. By contrast, other neighbourhoods are often described as foreign entities. The central or peripheral status of a given neighbourhood may have to do with the consonance or dissonance between the idealized image of the city in the rhetoric of local journalists and editors and the public image of the neighbourhood that local media contribute to producing and re-producing over time. We argue that the ethnic issue may function as a key variable in the media construction of the status of a neighbourhood in relation to the image of the city.

The third variable concerns the general relevance of hyper-local contexts in public debates and collective narratives. What interests us here is the relevance of neighbourhoods in general terms, rather than the particular relevance of specific neighbourhoods. One finding from the media section of the Concordia Discors project is that the general relevance of neighbourhoods in the public discourse is clearly higher in southern European cities.

\subsection{Images of the Neighbourhoods and 'Their Migrants/ Minorities' in the Local Media: Turin and Barcelona}

Before exploring the local/national nexus by focusing on extraordinary media phenomena such as moral panics, we will start by analyzing empirical data collected by surveying the local/hyper-local nexus (i.e. the conjunctions and differences among the images of neighbourhoods and the images of cities) in ordinary media coverage and the role played by the news dealing with immigrants in shaping discursive images of given places. The choice of neighbourhoods - two from Turin and two from Barcelona - was determined by the comparability between the data, which is enhanced by the similarities in both the social contexts (in both Italy and Spain neighbourhoods are significant and subject to specific recurrent media narratives) and the collected news items (in both cases items were taken from dailies gathered within an identical sample of one every five days in the period 2001-2010).

In the Barriera di Milano neighbourhood of Turin, 163 out of 257 news items deal with the neighbourhood by mentioning migrants, accounting for $63.4 \%$ of local coverage of the neighbourhood. In San Paolo in Turin, in contrast, the share of migrant-related items is just $17.4 \%$ (29 out of 167). In Barcelona's Poble Sec neighbourhood it is $16.52 \%$ and in Sagrada Família it is $4.72 \%$. What accounts for such differences?

One factor may be the previously mentioned deontological code adopted in Catalunya. If we compare the contents of local news dealing with immigration in Barriera di Milano and Poble Sec, we see that, despite a similar propensity to 
emphasize poverty and urban decay when dealing with immigrants, there is a huge difference in reporting crime news. In Poble Sec, we count only three items out of $41(7.3 \%)$. In Barriera di Milano crime news dealing with immigrants accounts for 48 out of $163(29.4 \%)$.

A second factor may be found in the image of neighbourhoods constructed by the media in relation to the city. In Making Local News, Kaniss (1991) showed 'how local journalists define what should be understood as local, namely by emphasizing issues which can be regarded as symbols of local identity. For example, by giving media attention to central city development projects' (Ekström et al. 2012: 256257). We argue that the embeddedness of such symbols in specific neighbourhoods might have consequences for the news-making mechanisms enacted by local journalists upon these neighbourhoods. The central idea is that journalists tend to preserve consolidated images in their work. This process of preservation and promulgation is effected through the routines of news selection and news framing.

If we consider the relationships that symbolically link the neighbourhoods to the cities, as they emerge from media analysis, the four neighbourhoods considered in this section are characterized by being central in two cases (Sagrada Família and San Paolo), peripheral in one case (Barriera di Milano, in spite of it being geographically semi-central, as we will see in more details below) and neither central nor peripheral in the last case (Poble Sec). In one case, the centrality acquired by the neighbourhood in relation to the city in media reports depends on the presence of a very important tourist attraction (the Sagrada Família church), whereas in the other (San Paolo), it depends on the neighbourhood's historical and ideological background. What we are claiming is that an image of a neighbourhood's centrality in the city narrative, shared by journalists, local politicians and other stakeholders alike, may influence the news-making mechanism adopted when dealing with it. In these cases, narrative cohesion at the neighbourhood level corresponds to the idealized image of the city that local journalists tend to preserve. This process may explain in part the huge difference between the frequency with which local news in San Paolo and Barriera di Milano covers immigrants within a conflict frame.

In San Paolo, many news stories about the neighbourhood produce a historical narrative, both in memorials/celebrations (of Liberation, Resistance and the young anti-fascist hero Dante Di Nanni), and through constant references to the past, evoking the industrial period. The neighbourhood is described as a working-class district, a cradle of values among which solidarity stands out. A series of events that took place in San Paolo have been journalistic opportunities to write and talk about the projects to transform Turin from an industrial city to a city of culture and tourism. At the same time, the area seems to become an ideal location for the narrative of historical events which Turin claims with pride. In Ruffini Park there is also an annual celebration for left-wing parties, another moment of celebration of a history that unites some of the residents and, foremost, for administrators who for years led both the city and the district in which the quarter is located. San Paolo thus becomes a location made up of places that transcend it. A symbol is created which continually projects the quarter beyond its borders. We claim that once this image is established, problematic events involving migrants are less likely to be selected and 
emphasized by journalists. This means that these events are less newsworthy than comparable events taking place in neighbourhoods with a peripheral narrative status.

This is the case of the Barriera di Milano neighbourhood in Turin, whose image presented in the media is clearly peripheral, despite its geographically semi-central position and the important role it played in Turin's great industrial history. News reports concerning this neighbourhood fail to mention its celebrated heroes or major historical events. The only historical figure whose name has been associated with the neighbourhood in the media is Pietro Cavallero, an infamous bandit from the 1960s, and that was in conjunction with the release of a film and exhibit dedicated to him. There is a conspicuous absence of any historical discourse that frames the neighbourhood in the light of its industrial and working-class past. No significant stories - those able to establish a shared memory and, ultimately, an image recognized by residents and recognizable to others - are evoked by the local media. The past exists only as a vague nostalgia that fuels discontent, not as history that can shed light on the present. In this context, which we could define as a historical memory void, the immigration issue emerges as the key issue in representing the neighbourhood. The vast majority of stories about the neighbourhood emerge within the framework of news referring to immigrants $(72 \%)$. These stories describe Barriera di Milano as a 'problem area', 'tough neighbourhood', 'poor neighbourhood', 'robbery district', 'quarter with many illegal immigrants', 'drug dealing and theft area', 'unsafe place', 'slum', 'neglected area', and so forth.

It is worth noting that this difference is not related to the capacity of immigrant groups or associations to gain a voice in the local media. Immigrants are not quoted frequently in the news, either in Barriera di Milano or in San Paolo. Furthermore, if we consider the case of San Paolo, we notice that the presence of immigrants remains marginal in the stories about the neighbourhood and, when they appear, it is on the occasion of specific celebrations, such as the Feast of the Peruvian Community. We may take this data as evidence of a journalistic effort to offer a peaceful narrative of San Paolo. Despite its frequent representation as a 'place of solidarity', immigrants are not only largely unvoiced in the media but also excluded as referents in the media construction of the neighbourhood's image.

It is interesting to compare this data with that related to Poble Sec. In Poble Sec the distribution of news dealing with immigrants both within a conflict frame and a cooperation frame are similar to those in San Paolo (with a slightly larger number of stories on conflict, but also more stories on integration policies). In Poble Sec, however, immigrants are more often given a voice in the news: residents with nonSpanish origins are quoted 16 times, compared with the nine times residents of Spanish origins are quoted. As for local stakeholders and local politicians, they are quoted 8 times each.

This brings us to the third element worth accounting for: the role played by organized official and unofficial sources, whether local or hyper-local, in the newsmaking process. In Barriera di Milano, an absence of organized voices at the hyper-local level gave rise to the predominance of both official voices from law enforcement actors and the voices of single residents or temporary committees and 
protest groups. In a smaller but significant proportion, the comments negatively labelling the neighbourhood are from journalists, mostly aimed at summarizing the findings from meetings in which demographic or crime statistics are provided. In San Paolo and Poble Sec organized groups of residents (associations and other hyper-local stakeholders) are both quoted and taken as sources in the news, while in Sagrada Família they are absent. These data contribute to explaining both the endogenous/exogenous nexus - which see some of the neighbourhood's problems represented as if they were always generated elsewhere and others as if they were always produced inside the neighbourhood - and the local/hyper-local nexus, which produces for some neighbourhoods a sense of being both a city symbol and a place with its own identity, while for other neighbourhoods the symbolization produces a de-contextualisation at the hyper-local level.

For the endogenous/exogenous nexus we may refer again to San Paolo and Poble $\mathrm{Sec}$ on the one hand, and to Barriera di Milano on the other. In the former two, news reports on conflict situations are often described as external: muggers and drug dealers who do not live in the neighbourhood but who periodically "target" it. Regarding Poble Sec, these exogenous narratives are often related with the neighbourhood's proximity to the neighbourhood of Raval, where, 'at least during the past 20 years, some form of conflict linked by some stakeholders to immigrants have taken place (e.g., prostitution, drug dealing, dirtiness, noise, infections, etc.). At some moments, this geographical proximity can contribute to spreading social alarm from Raval to Poble Sec' (Morén-Alegret et al. 2012: 62). The contrary happens for Barriera di Milano, where many news stories that have been presented as news about the neighbourhood actually refer to places that, in strict administrative terms, lie outside the neighbourhood, such as the Roma camps of Lungo Stura and Arrivore. These places have been characterized in terms of problems and marked by the presence of foreigners (Roma, African drug dealers, etc.). These stories have turned Barriera di Milano into the epicentre of the city's "security problem". We argue that the absence of organized voices other than temporary protest groups in the neighbourhood is part of the symbolic production of a stigma affecting Barriera di Milano.

For the local/hyper-local nexus we refer to Sagrada Família and to San Paolo. The central role occupied by the two neighbourhoods in the narratives related to their respective cities has often been marked in the local media in explicit ways, but the majority of the news items mentioning San Paolo produce an image of the neighbourhood and its residents, while the vast majority of news items mentioning Sagrada Família do not. In Sagrada Família the stories about the neighbourhood are stories about the church. The labelling of the location is a function of its international role in conferring a touristic image to the city of Barcelona. The values contained in the image of Sagrada Família are found in the church, not in the neighbourhood. Out of 30 news items dealing with immigrants in Sagrada Família, only four took place exclusively in the neighbourhood. In the vast majority of cases (26 out of 30), news stories mention Sagrada Família in conjunction with other neighbourhoods. This data can be taken as evidence of the media's tendency to avoid focusing on the neighbourhood. Far from reinforcing the visibility of the local concerns in the news, the centrality of Sagrada Família tends instead to obscure them. 


\title{
2.3 Moral Panics and the Ethnic Issue: The Local Goes National?
}

\author{
A Sequential Structure for Moral Panics
}

Cohen (1972: 9) opened his classic study of moral panics with these words:

\begin{abstract}
Societies appear to be subject, every now and then, to periods of moral panic. A condition, episode, person or group of persons emerge to become defined as a threat to societal values and interests; its nature is presented in a stylised and stereotypical fashion by the mass media; the moral barricades are manned by editors, bishops, politicians and other right thinking people; socially accredited experts pronounce their diagnosis and solutions; ways of coping are evolved or (more often) resorted to; the condition then disappears, submerges or deteriorates and become more visible (...) Sometimes the panic passes over and is forgotten, except in folklore and collective memory; at other times it has more serious and long-lasting repercussions and might produce such changes as those in legal and social policy or even in the way society conceives itself.
\end{abstract}

In the original formulation, Cohen (1972) traced a sequential structure for moral panics, derived from disaster research. The stages indicated by Cohen are Warning, Impact, Inventory and Reaction. In a recent work, Maneri (2013: 172) remarks that 'the stages seem to work at disjointed analytical levels'. Confronting Cohen's stages with those indicated for the study of media hypes (Vasterman 2005), Maneri (2013) reworks the sequential structure in order to offer a useful tool for empirical studies of media-driven moral panics. The reformulation includes five stages: Warning, Impact, Propagation, Reaction and Latency. In the Warning stage, events are covered according to routine journalistic norms. In the Impact stage, coverage is disproportionately high compared to usual journalistic norms. In the Propagation stage, 'otherwise minor events gain strong visibility thanks to the newsworthiness of the established news theme, making them appear - to journalists as well as the public to be new occurrences of the ongoing emergency' (Maneri 2013: 176). In the Reaction stage, diagnoses and solutions are offered from experts and moral entrepreneurs, and 'extraordinary law enforcement measures are taken'. The Latency stage means a return to the usual level of media coverage.

\section{(Serial) Moral Panics and the Ethnic Issue}

The first study of moral panics to deal with ethnic and racial issues was the now classic analysis of episodes of mugging in Britain during the 1970s, published under the title Policing the Crisis (Hall et al. 1978). After Policing the Crisis, the concept of moral panic was explored in several studies dealing with the journalistic representations of immigration and ethnic minority issues, particularly analyzing innercity riots in Britain, and then in France in the coverage of the banlieues.

Moral panics on immigration are reported to be more frequent nowadays in southern European countries (ter Wal 2002). Italian, Greek and Spanish studies 
have found examples of the media phenomenon of moral panic in the 1990s and in the following decade.

Critcher made a distinction between individual and serial moral panics, with serial moral panics starting and ending more than once in cyclical ways, supported by a script that, once activated, works as a prototype. Among serial moral panics on immigration there are panics over the massive arrivals of undocumented migrants and crime panics. Between the two, there is a typical serial panic of more local interest, related to clashes, riots or protests over urban decay involving natives and immigrants in neighbourhoods.

As Critcher (2006: 12) points out, '[m]oral panics also have a discursive legacy. They establish the terms in which the issue has to be debated now and for the foreseeable future. Recurrent episodes will be mapped onto the established discursive framework, often connoted by a phrase'. In other words, local differences need to be silenced in order for the particular local events to unambiguously fit the framework. This does not mean that the local is not a key factor in moral panics, as we shall see below.

\section{The Failures of Moral Panics: Discussing the Neighbourhood's Power}

McRobbie and Thornton (1995) have argued that in modern polyphonic societies 'classic' consensual moral panics are now unusual.

\footnotetext{
The proliferation and fragmentation of mass, niche and micro-media and the multiplicity of voices, which compete and contest the meaning of the issue subject to moral panic, suggest that the ... models are outdated in so far as they could not possibly take account of the labyrinthine web of determining relations which now exists between social groups and the media, 'reality' and representation (in Critcher 2006: 267).
}

This argument is partly accepted in the recent literature but it does not seem to be supported by empirical data, if we accept the general finding that cases of moral panic over immigration are not reported to have diminished in recent years. As mentioned above, they are reported to have diminished in some countries but they have become more frequent in southern European countries. Maneri (2013) argues for an analytical distinction between the representation of events and the reaction to the perceived threat. It is largely a distinction between the media sphere and the social sphere. In this critical view, McRobbie and Thornton over-emphasize the plurality of voices characterizing the social environment by under-estimating the integration of the information system.

The interdependence between various media platforms and channels, their cutting and pasting of each other's content, and their reliance on the same organized sources seems to enhance rather than reduce a consensual representation of the 'important hard facts' that journalists think are the epistemological basis of reality. The Propagation stage ensures that an amplification spiral occurs as a consequence of an established general consensus about which facts deserve the most attention in a given situation. Neither citizen journalism, blogs, nor ethnic media can counter a 
consensual representation of dramatic events, especially in the first crucial few weeks (Maneri 2013: 185-186).

One of the first studies dealing with the failure of a moral panic is by Curran (1987), who analyzed cases in London during the period 1981-1986. Since then, the conditions for the failure or success of moral panics have been called into question in several studies. There is now a general consensus in the literature about the factors leading to the failure of a moral panic. Critcher (2006: 11) has summed up these factors in the following six points:

- A failure to establish an issue as sufficiently new or threatening to provoke the formulation of a new label or the resuscitation of an old one;

- A lack of media unanimity in accepting the legitimacy of the label and its connotations;

- An attempt to brand as folk devils groups whose social status precludes such vilification;

- Opposition to the moral panic from an alliance of effectively organized pressure groups (counter-claims makers);

- Divisions among elite groups over the seriousness of the problem or its causes and remedies when its seriousness is agreed;

- The absence of available and effective remedies.

We may add to this list the eventual absence of further events which the media and moral entrepreneurs are able to put into the same discursive category, so as to interpret them as new episodes of the ongoing phenomenon.

A common finding in moral panic studies dealing with immigration and ethnic minority issues is that moral panics are typically built around local events and protests and - if accomplished - are constructed as a national social problem by downplaying the local context in favour of a fixed repertoire built within a national frame. Notwithstanding this finding, in the debate about the conditions for the success or failure of a panic, the local/national nexus has rarely been discussed in detail. For instance, for the 'effectively organized pressure groups' scholars usually refer to national actors. When the local is considered, the actors considered are mayors or other prominent city-level politicians and organizations. In the cases of moral panics dealing with immigration, the studies often underline the difficulty for immigrants or refugees to be organized in such a way as to become a collective voice for the media. This has been taken as an explanation for the decrease in the number of moral panics in countries with a longer history of immigration and the increase in countries with a shorter history. In the former, it is supposed that immigrant communities are better organized than in the latter. The only hyper-local actors considered by researchers are protest groups.

The absence of local protesters contributing to the identification of a folk devil might be cited as a key element in countering the consensual representation needed in moral panics. For instance, some events related to immigrants that are represented as being problematic might have no evident implication for the natives, despite the existence of a media consensus in creating an image of immigrants as a 
social pathology. Nevertheless, the presence of a pressure group of protesting native residents given a voice by the media might be a sufficient condition to start a moral panic.

\section{Case Studies from the Neighbourhoods}

In the following pages we present four episodes, all related to the immigration issue and defined as social problems, characterized by peaks in local media coverage of four different neighbourhoods. The episodes which started the tentative panics vary from a fight involving two groups of immigrants of different ethnic origins, followed by a street protest, to structural conflicts framed as interethnic conflicts, to the presence of an informal settlement of refugees. Although these episodes differ widely and are to some extent incomparable, a common process nevertheless emerges which is typical of moral panics and which serves as the focus of our analysis. We consider these episodes as examples of complete or partial failures of moral panics and we argue that the neighbourhoods played important roles in countering exogenous narratives from moral entrepreneurs. The concept of narrative cohesion at the hyper-local level is pivotal, but we claim that the multiple meaning inscribed in this concept needs further investigation, which we attempt in the conclusion. The four neighbourhoods are the German neighbourhoods of Werderau and Langwasser in Nuremberg and the Italian neighbourhoods of via Padova and San Paolo, respectively in Milan and Turin. Analysis of news items related to via Padova was carried out for the Italian section of the Concordia Discors project (Pogliano 2012) and is drawn on to inform the discussion presented in the following pages. Nevertheless, a brief description introducing the neighbourhood will prove helpful.

Via Padova is fairly centrally located in the city of Milan and, although not officially a neighbourhood, is usually considered as such by its residents and the media. The number of foreign residents in via Padova has tripled over the past decade and accounts for about $30 \%$ of the total, almost twice the city average. The percentage of single men is also higher, evidence of the ongoing process of foreigners settling in the area. Also of note is the large number of foreign-run businesses in the neighbourhood. The number of foreign business owners in via Padova, already higher than in the rest of the city, is constantly on the upswing, making it one of the most socially and economically dynamic areas of the city (Ponti and Pozzi 2012).

Unlike other studies that map the development of a moral panic through news analysis alone, here we present a case of media analysis largely supported by the ethnographic studies reported in this volume. This approach allows us to observe the failure of a media-driven moral panic not just subsequent to an initial process of panic in the media (according to the above-mentioned stages first introduced by Cohen), but also when there has been no remarkable spike in the frequency of media coverage. In our analysis of the last two cases (Langwasser in Nuremberg and San Paolo in Turin), the failure of moral panic cannot be accounted for by quantitative media analysis alone, but can easily be understood by taking a qualitative approach. 


\section{Via Padova in Milan}

Via Padova has been characterized by a relatively low level of coverage by local media since 2005. The frequency has increased since that year, accelerating in 2007, and peaking in 2010. The visibility of the neighbourhood in the media for the 11 years analyzed (2001-2011) consisted almost entirely of news dealing with immigrants, the vast majority of which was reported in a social conflict frame. From 2007 onwards, news from via Padova presented two main frames, each with its supporters. The first and more frequent frame was about interethnic conflict caused by the excessive presence of illegal immigrants. This frame was supported by local politicians from right-wing parties who administered the city of Milan and by a protest group of native residents accusing immigrants of being the main cause of decay and crimes. The second and less frequent frame was about blaming the city administration for not promoting integration policies and, so to speak, for discriminating against the neighbourhood. It was supported by an alliance of civil society organizations originating from interethnic schools and by charismatic priests managing an oratory attended by young people primarily of non-European origins. A series of minor episodes of conflict in the neighbourhood have been covered by the local media for years (with the mentioned increase since 2007), portraying the facts within a conflict frame supported and reacted to by all of the actors involved. We may see this period as the Warring stage of a moral panic phenomenon. On the 13th of February 2010, two small groups of young residents, one of North African and the other of Latin American origins, were involved in a fight during which a young man originating from Egypt was killed. That night, numerous people of North African origins protested in the neighbourhood's streets. Some of them burned cars and broke shop windows. This key event and its media coverage may be presented as the Impact stage of a moral panic phenomenon. In the aftermath, the Reaction stage saw moral entrepreneurs embark upon a serial labelling of the area as a homogenous environment where the native residents were largely damaged by the massive presence of illegal immigrants. The event was immediately framed by the city administration as an intolerable riot denoting the high degree of danger in the area.

The case of via Padova in Milan is an example of a partial failure of a moral panic for a variety of reasons among which the narrative cohesion of the neighbourhood plays a role. In via Padova a shared narrative emerged and gained visibility partly as a consequence of the reactions by moral entrepreneurs and the law and order solutions imposed by the mayor, both of which were perceived as excessive and unsuitable to the context. Although other elements contributed to the failure of the moral panic (i.e. the divisions among elite groups at the national level over the seriousness of the problem and the absence of further events to be placed by the media under the label of neighbourhood insecurity, which would have produced a Propagation stage) there is no doubt that endogenous counter-claims by organized groups of residents played a key role and were partly triggered by the panic construction itself. Many residents identified not the immigrants but key figures in the city administration and the media as being the out-group. The event titled "Via 
Padova è meglio di Milano" (Via Padova is a better place than Milan), organized by a group of local associations and NGOs a few months after this event is a clear sign of this oppositional narrative.

\section{Werderau in Nuremberg}

In Werderau interethnic conflicts developed at the beginning of the 2000s, after many years of peaceful relations. As described in detail in the chapter by C. Köhler, the Werderau conflict has been framed as an interethnic conflict between Germans and Turks, downplaying both the structural dimension of the conflict (between investors and long-term house renters) and the divisions between old and new Turkish inhabitants. In other words, the structural conflict has been ethnicized. In framing the conflict this way, a key role has been played by anti-immigrant groups from outside the neighbourhood. An activist movement associated with the neoNazi party NPD and the regional group called 'Ausländerstopp' both interfered in the conflict and increased the interethnic tensions. Moral entrepreneurs found the proper terrain for localizing the anti-immigrant sentiment in the inhabitants' shared sense of having been abandoned by the city administration for years. This mechanism of reframing an already existing oppositional feeling (i.e. being abandoned by wider-scale local politicians) emerges as an important part of the moral entrepreneurs' initiatives.

In 2002 we can observe a spike in news from Werderau in the newspapers analyzed, accompanied by the increased labelling of the area as a 'problem quarter' within a social conflict frame. The extraordinary rate of coverage decreased quickly in the following year and became very low in 2004, along with a decrease of the conflict frame and an increase in the cooperation frame.

The first element in the partial failure of the Werderau moral panic was the absence of a law and order solution. In Werderau the moral panic escalation was countered primarily through a mediation coordinated by a conflict manager appointed by the mayor. His task was to ease the tensions and to end the open conflict in the neighbourhood (see Köhler 2012). Another element for the partial failure of the moral panic came from the relative absence of a key event carrying strong emotional connotations in the frame of the interethnic conflict. Only minor events and pseudo-events were reported, forming a sense of Propagation without Impact. Nevertheless, the episode of Werderau is - among the cases we are discussing here - the one most likely to be described as a successful case of moral panic. The reason for this partial success, in our view, can be attributed to the relative incapacity of the neighbourhood residents and civil associations to counter the moral entrepreneurs' narratives which dominated media coverage in the first months of the panic. 


\section{Langwasser in Nuremberg}

In Langwasser, an interethnic conflict developed in 2009 in reaction to the development of the Intercultural Gardens (see the chapter by C. Köhler for details). Word of the project spread quickly after it was first presented, and the neighbourhood became increasingly disgruntled with what it considered to be an imposition by city government. A petition against the garden project was circulated in Langwasser and a protest was mounted by a right-leaning local resident living near the proposed garden site. The growing public opinion was that the project favoured migrants, who, in the guise of gardeners, would be able to invade the property rights of the quiet community's residents. Anti-immigrant right-wing activists from outside Langwasser echoed and reinforced this perception. The conflict was coming to be viewed more and more as a migrant-majority conflict. Media support of right-wing agitation contributed to the ethnic framing of the dispute, accelerating the spread of inter-group conflict.

As in Werderau, a mechanism of reframing an already existing feeling of opposition emerges as an important component of the moral entrepreneurs' initiatives.

A second meeting was called between the district coordinator and the local residents to dispel the many rumours circulating about the garden project. The district coordinator appealed to the media not to give anti-immigrant protesters coverage or support for their propaganda. The media complied, becoming harsher in its criticism of the right-wing protests and providing a more favourable image of the Intercultural Gardens. This, along with mediation between the stakeholders, contributed to easing the conflict. A counter-force was mustered, and political parties and district organizations stepped up in favour of the garden project. Numerous organizations and associations joined in to protest against the involvement of rightwing organizations and the ethnicization of the conflict. A detailed analysis of the Langwasser Intercultural Gardens conflict can be found in chapter "Rise and Resolution of Ethnic Conflicts in Nuremberg Neighbourhoods" by C. Köhler.

Regarding media coverage, one observes a spike in news from Langwasser in 2009. The general tendency to present the news from Langwasser within a social conflict frame of reference - which also emerges from an analysis of previous years' coverage of the neighbourhood - is clearly maintained in 2009. Nevertheless, it is interesting to note that this tendency had been partially subverted by the end of the year. In 2010, as a response to the growing risk for panic, the social conflict frame was being displaced by greater output within a cooperation frame. The most important element precluding a moral panic was that no violent events occurred. But, together with this missing element, there is also evidence supporting the thesis that the strong policy community of Langwasser and the emergence of narrative cohesion (expressed mainly in terms of political orientation) in response to the rightwing propaganda was able to influence the local media, reframing the events through the introduction of new voices to be quoted and focused on in the news. Instead of directing attention to the issue of migrants and integration, what emerges here from the media narratives is the symbolic need to distinguish one group (the majority in the neighbourhood) from another (the moral entrepreneurs from outside the 
neighbourhood). In other words, the local shared narrative can be considered a key reason for which moral panic failed to materialize in Langwasser. The narrative emerged and gained visibility thanks to the strength of the policy community. As with the via Padova case discussed above, the media in Langwasser acted as a sort of mirror that allowed the residents to see in its reflection how far their true concerns were from those being portrayed as their concerns by the actors in the spotlight (i.e., the moral entrepreneurs from outside the neighbourhood), who were actively influencing the media's framing of the events.

\section{San Paolo in Turin}

The case of African refugees (from Somalia, Ethiopia and Eritrea) who occupied the former San Paolo clinic, situated in the homonymous Turin neighbourhood, in 2009 may be taken as an example - perhaps the most impressive - of the capacity of a neighbourhood to counter exogenous narratives and pseudo-event production. This local conflict did not find significant space in the news media we analyzed, despite the fact that moral entrepreneurs from outside the neighbourhood tried to frame the event as both a case of urban decay and of local disorder involving the natives in clear opposition with the refugees. In San Paolo, the refugees were not quoted in the media as an organized group, and the associations advocating for the refugees failed - at least in part - to obtain a serious role in the narrative. The refugees did not obtain visibility other than the typical use of images showing the 'desperate conditions' in which they lived and sound-bites from brief interviews in the regional TV news reports. Nevertheless, in San Paolo moral entrepreneurs did not gain local support for their claims, either from the city administrators or the residents.

There is no spike in local news coverage in 2009. The unaltered level of the coverage is an essential element supporting the claim that the moral panic in San Paolo blew beneath the surface.

It is evident that the local reasons for this clear failure of moral panic are different from those registered in the Milan neighbourhood of via Padova. In via Padova the opposition to the moral panic was carried out mainly by an alliance of effectively organized pressure groups to which the media attributed the role of counterclaims makers - in opposition to administrators and national right-wing politicians - but also to protest groups at the hyper-local level. In San Paolo, coherent narratives emphasizing neighbourhood solidarity have long been shared by residents, local politicians and most local journalists.

\section{Conclusions}

As ter Wal (2002: 36) observes, 'several studies have remarked that inhabitants of neighbourhoods that become the object of special issue reporting (because of conflict, protests or decay) did not recognize themselves or their positions in the way 
their problems or lives were shown in the media'. This typically happens because the local dimension is under-investigated in the media construction of a moral panic. As Maneri (1998) pointed out, local protest groups are taken by the media as representative of the entire neighbourhood, silencing native as well as immigrant residents' critical voices. We argue that this is often the case in neighbourhoods where a shared narrative offering a basis for resisting and countering official voices from a larger scale (the city, the region or the state) is absent or weak, as in the case of Werderau. In most of the episodes of failed moral panic described above, we have discussed the local factor. Without denying the importance of other factors, we argue that what we propose to call 'narrative cohesion' within a neighbourhood may be key in some contexts.

Nevertheless, narrative cohesion may be constituted in different ways. It may include both local journalists and local politicians (San Paolo) or exclude both of them (via Padova). It may be, at least in part, the product of inhabitants' reactions to politicians' and journalists' claims (via Padova). It may be seen as the result of a strong presence of associations and local NGOs which are well-organized and considered reliable by the media (via Padova), or it may be seen as an informally shared, though not officially advocated, agreement in finding causes for the neighbourhood malaise other than those proposed by moral entrepreneurs (Langwasser). It may refer to cohesion among natives and immigrants leading to greater visibility of the latter (via Padova), or it may signify a narrative where immigrants remain largely invisible and their role appears to be of little importance in countering the threat of moral panic (Langwasser and San Paolo).

To conclude, we may say that narrative cohesion derives from the strength of a policy community on a local scale, but that the community itself may be reinforced or weakened in its public efforts to communicate by media narratives and their legacy. This can take the form of a wave of attention that temporarily affects the neighbourhood and its image, but it can also be the product of a long-term definition of the neighbourhood and its status in the 'tale of the city'. The empirical data we have accounted for in this chapter demonstrate the complexity and circularity of the relationship between the policy community and the media image of a given neighbourhood. In the construction of such an image, immigration is often key, but the role played by immigrants is far from being clearly defined. What we noticed is an over-emphasis on migrants in the news but a lack of their voices in reports from neighbourhoods which journalists consider to be peripheral in producing the ideal image of a city and which are characterized by a weak policy community unable to produce a shared counter-narrative. The cases of San Paolo and Poble Sec appear to be evidence of the essential role played by strong policy communities in normalizing the presence of migrants in media narratives. When policy communities are effective, the media tends to present negative events concerning interethnic relationships as incidents that do not diminish the neighbourhood's general image as a place in which conflict is marginal and under control. 
Open Access This chapter is distributed under the terms of the Creative Commons AttributionNoncommercial 2.5 License (http://creativecommons.org/licenses/by-nc/2.5/) which permits any noncommercial use, distribution, and reproduction in any medium, provided the original author(s) and source are credited.

The images or other third party material in this chapter are included in the work's Creative Commons license, unless indicated otherwise in the credit line; if such material is not included in the work's Creative Commons license and the respective action is not permitted by statutory regulation, users will need to obtain permission from the license holder to duplicate, adapt or reproduce the material.

\section{Bibliography}

Alsultany, E. (2012). Arab and Muslims in the media: Race and representation After 9/11. New York: New York University Press.

Article 19. (2003). What's the story? Results from research into media coverage of refugees and Asylum seekers in the UK. London: Article 19. http://www.article19.org/docimages/1695.pdf

Banon-Hernàndez, M. (2002). Spain (ES). In J. ter Wal (Ed.), Racism and cultural diversity in the mass media. An overview of research and examples of good practice in the EU Member States, 1995-2000 (pp. 173-202). Vienna: European Monitoring Centre on Racism and Xenophobia. http://www.eumc.eu.int/

Becker, H. (1963). The outsiders. New York: Free Press.

Belluati, M. (1998). Un quartiere in protesta. Il caso San Salvario tra rappresentazioni sociali e immagini mediali. Unpublished $\mathrm{PhD}$ dissertation.

Bennett, S., ter Wal, J., Lipinski, A., Fabiszak, M., \& Krzyzanowski, M. (2011). Mediva thematic report 2011/02: Media Content. www.eui.eu/Projects/MEDIVA/Reports.aspx

Binotto, M., \& Martino, V. (Eds.). (2004). Fuori luogo. L'immigrazione e i media italiani. Rome: Eri/RAI.

Cohen, S. (1972). Folk devils and moral panics. London: Routledge.

Critcher, C. (2003). Moral panics and the media. Maidenhead: Open University Press.

Critcher, C. (Ed.). (2006). Critical readings: Moral panics and the media. Maidenhead: Open University Press.

Curran, J. (1987). The boomerang effect: The press and the battle for London, 1981-6. In J. Curran, A. Smith, \& P. Wingate (Eds.), Impacts and influences (pp. 113-138). London: Methuen.

Ekström, M., Johansson, B., \& Larsson, L. (2012). Journalism and local politics. In S. Allan (Ed.), The Routledge companion to news and journalism (pp. 256-266). London: Routledge.

Flood, C., Hutchings, S., Miazhevich, G., \& Nickels, H. (2012). Islam, security and television news. London: Palgrave Macmillan.

Franklin, B., \& Murphy, D. (1991). What news? The market, politics and the local press. London: Routledge.

Goode, E., \& Ben-Yehuda, N. (1994). Moral panics. The social construction of deviance. Chichester: Wiley-Blackwell.

Grossi, G. (1995). Ritratto di una società poco razzista. Immigrazione e comunità locale tra coesistenza interetnica e risposta istituzionale. In M. Belluati, G. Grossi, \& E. Viglongo (Eds.), Mass media e società multietnica (pp. 49-60). Anabasi: Milan.

Hall, S., Critcher, C., Jefferson, T., \& Clarke, N. (1978). Policing the crisis: Mugging, the state and law and order. London: Macmillan.

Hutchings, S., Flood, C., Miazhevich, G., \& Nickels, H. (Eds.). (2011). Islam in its international context: Comparative perspectives. Cambridge: Scholars Publishing.

Kaniss, P. (1991). Making local news. Chicago: University of Chicago Press. 
Karim, H. K. (2011). Covering Muslims: Journalism as cultural practice. In S. Allan \& B. Zelizer (Eds.), Journalism after September 11 (pp. 131-146). New York: Routledge.

Köhler, C. (2012). Concordia discors: Nuremberg final report. Available at: http://www.concordiadiscors.eu

Krzyżanowski, M. (2012). From nationalism, anti-semitism and revisionism to mediatisation, securitisation and Islamophobia: On continuities and shifts in recent discourses of the Austrian Freedom Party (FPÖ). In R. Wodak, B. Mral, \& M. Khosravinik (Eds.), Right-wing populism in Europe (pp. 135-148). London: Bloomsbury Publishers.

Law, I. (1997). Privilege and silence. 'Race' in the British news during the general election campaign. Research report for the Commission of Racial Equality. Leeds: University of Leeds Press.

Maneri, M. (1998). Lo straniero consensuale. In A. Dal Lago (Ed.), Lo straniero e il nemico (pp. 236-272). Genoa: Costa \& Nolan.

Maneri, M. (2013). From media hypes to moral panics: Theoretical and methodological tools. In J. Petley et al. (Eds.), Moral panics in the contemporary world (pp. 171-192). London: Bloombsbury.

Maneri, M. \& ter Wal, J. (2005). The criminalisation of ethnic groups: An issue for media analysis. Forum: Qualitative Social Research, 6(3). Available at: http://www.qualitativeresearch.net

Marletti, C. (Ed.). (1995). Televisione e islam. Immagini e stereotipi dell'islam nella comunicazione italiana. Turin: RAI/Nuova ERI.

McRobbie, A., \& Thornton, S. (1995). Re-thinking moral panics for multi-mediated social worlds. British Journal of Sociology, 46(4), 559-574.

Morén-Alegret, R., Mas, A., \& Wladyka, D. (2012). Concordia discors: Barcelona final report. Available at: http://www.concordiadiscors.eu

Morey, P., \& Yaqin, A. (Eds.). (2011). Framing Muslims: Stereotyping and representation after 9/11. Cambridge: Harvard University Press.

Niessen, J., \& Huddleston, T. (2010). Handbook on integration (3rd edn). European Commission. Available at: http://www.integration.eu

Pastore, F., \& Ponzo, I. (2012). Concordia discors: Synthesis report. Available at: www.concordiadiscors.eu

Pogliano, A. (2010). Le rappresentazioni fotogiornalistiche dell'immigrazione nel Mediterraneo sulla stampa periodica italiana, Research report. Available at: www.fieri.it

Pogliano, A. (2012). Media locali e migrazioni: Raccontare i quartieri. In F. Pastore \& I. Ponzo (Eds.), Concordia discors. Convivenza e conflitto nei quartieri di immigrazione (pp. 257-289). Carocci: Rome.

Pogliano, A., \& Zanini, R. (2010). L'immaginario e le immagini degli immigrati: un percorso qualitative. In L. Gariglio, A. Pogliano, \& R. Zanini (Eds.), Facce da straniero. 30 anni di fotografia e giornalismo sull'immigrazione in Italia (pp. 103-187). Milan: Bruno Mondadori.

Ponti, P., \& Pozzi, S. (2012). Zona di via Padova. Un quartiere di immigrazione dalla forte identità popolare. In F. Pastore \& I. Ponzo (Eds.), Concordia discors. Convivenza e conflitto nei quartieri di immigrazione (pp. 169-179). Carocci: Rome.

Roggeband, C., \& Vliegenthart, R. (2007). Divergent framing: The public debate on migration in the Dutch Parliament and media, 1995-2004. West European Politics, 30(3), 524-548.

Soravia, G. (Ed.). (2000). L'immagine dell'Islam nei media italiani. Roma: Commissione per l'integrazione, Dipartimento degli Affari Sociali, Working paper no. 7.

Stopfner, M. (2010). Stereotype Bilder von Migranten in Tiroler Medien. Presentation at Medientag 2010 der Universitaet Inssbruck: Medien und Minderheiten.

Stopfner, M., \& Vorhofer, H. (2011). Zuwanderung, Asyl und Migration in Tiroler Printmedien. In F. Karlhofer \& G. Pallaver (Eds.), Politik in Tirol. Jahrbuch 2011. Innsbruck: StudienVerlag.

Ter Wal, J. (Ed.). (2002). Racism and cultural diversity in the mass media. An overview of research and examples of good practice in the EU Member States, 1995-2000. Vienna: European Monitoring Centre on Racism and Xenophobia. Available at: http://www.eumc.eu.int/.

Thiele, M. (2005). Flucht, Asyl und Einwanderung im Fernsehen. Konstanz: UVK Verlagsgesellschaft. 
Thompson, J. B. (1995). The media and modernity. A social theory of the media. Stanford: Stanford University Press.

Thompson, K. (1998). Moral panics. New York: Routledge.

Van Dijk, T. (1988). News analysis. Case studies of international and national news in the press. Hillsdale: Erlbaum.

Van Gorp, B. (2005). Where is the frame? Victims and intruders in the Belgian Press Coverage of the Asylum Issue. European Journal of Communication, 20(4), 484-507.

Vasterman, P. (2005). Media-hype. Self-reinforcing news waves. Journalistic standards and the construction of social problems. European Journal of Communication, 20(4), 508-530.

Wilkins, L. T. (1964). Social deviance: Social policy, action and research. London: Tavistock.

Yildiz, Y. (2009). Turkish girls, Allah's daughters, and the contemporary German subject: Itinerary of a figure. German Life and Letters, 62(4), 465-481. 